\title{
Resurrection of the name Albula pacifica (Beebe, 1942) for the shafted bonefish (Albuliformes: Albulidae) from the eastern Pacific
}

\author{
Edward Pfeiler \\ Centro de Investigación en Alimentación y Desarrollo, A.C., Unidad Guaymas, Apartado Postal 284, Guaymas, \\ Sonora C.P. 85480, México. Phone: +52-622-221-6533; epfeiler@asu.edu
}

Received 23-XI-2007. Corrected 01-III-2008. Accepted 11-III-2008.

\begin{abstract}
The name Albula nemoptera (Fowler, 1911) is currently applied to the Shafted, or Threadfin, Bonefish (Albuliformes: Albulidae) inhabiting the tropical coastal waters of both the western Atlantic and eastern Pacific. In the present paper I provide a brief review of the taxonomy and nomenclature of $A$. nemoptera, and argue that the available morphological, biogeographical and molecular evidence supports resurrecting the name $A$. pacifica (Beebe, 1942) for the population of A. nemoptera from the eastern Pacific. Rev. Biol. Trop. 56 (2): 839-844. Epub 2008 June 30.
\end{abstract}

Key words: cryptic species, Elopomorpha, mitochondrial DNA, molecular systematics, speciation.

The Shafted, or Threadfin, Bonefish from the tropical coastal waters of the western Atlantic and eastern Pacific (type locality: Santo Domingo, Dominican Republic) is currently recognized as a single species, Albula nemoptera (Fowler, 1911). Although A. nemoptera originally was assigned to the genus Dixonina Fowler 1911, Rivas and Warlen (1967) proposed that Dixonina should be placed into the synonymy of Albula Scopoli, 1777 , an arrangement which generally has been followed for forty years (Nelson et al. 2004), and which recently has received support from mitochondrial DNA studies (Pfeiler et al. 2006, Bowen et al. 2008).

In the eastern Pacific, A. nemoptera is distributed from Ecuador to the outer Pacific coast of Baja California Sur (BCS), Mexico (Castro-Aguirre et al. 1999, Pfeiler et al. 2002, Robertson and Allen 2006). Although present in the southern Gulf of California at Mazatlán, Sinaloa (Rivas and Warlen 1967, van der Heiden and Findley 1990), and at La Paz, BCS (Balart et al. 1995), the apparent lack of collection records from the central and northern gulf (Pfeiler et al. 2002) indicates that it may be rare, or absent, in this region. In the western Atlantic and Caribbean, A. nemoptera is found from the Greater Antilles, Panama and the northern coast of South America, south to Brazil (Rivas and Warlen 1967, Lopes and Sampaio 2002, Loebmann and Vieira 2005).

In 1942, William Beebe described the Shafted Bonefish from the eastern Pacific as a distinct species, Dixonina pacifica (type locality: Port Culebra, Costa Rica). Beebe's (1942) material included 19 specimens from the Pacific, but published records of only two Atlantic specimens (Fowler 1911, Metzelaar 1919) were available at that time for morphological comparisons. Hildebrand (1963) did not recognize $D$. pacifica, and placed it into the synonymy of $D$. (= Albula) nemoptera. Although Berry (1964) argued in support of retaining the name $A$. pacifica, Rivas and Warlen (1967), after conducting a more detailed morphological analysis of Atlantic and Pacific specimens, concluded that there was 
no basis for separating them as two species. Although the name A. nemoptera has been generally accepted as applying to both Atlantic and Pacific populations of the Shafted Bonefish (van der Heiden and Findley 1990, Bussing and López 1993, Balart et al. 1995) I argue here that there is now sufficient evidence for resurrecting the name $A$. pacifica for the population from the eastern Pacific.

Morphological Comparisons: Because of the historical importance of the work of Rivas and Warlen (1967) regarding the placement of A. pacifica into the synonymy of $A$. nemoptera, a brief summary of their findings is provided here. Rivas and Warlen (1967) analyzed 23 morphometric characters, expressed as percent standard length (SL), in nine Atlantic and seven Pacific specimens of juvenile and adult $A$. nemoptera of similar mean length (246 and 205 $\mathrm{mm}$ SL, respectively). In addition, 14 meristic comparisons were conducted on 20-28 Atlantic specimens and 16-21 Pacific specimens. The morphological differences between individuals from Atlantic and Pacific populations were found to be slight, with overlap seen in most characters. There was, however, one exception. Table 2 of Rivas and Warlen (1967) shows that mean lower caudal-fin lobe length was $20.0 \%$ SL (range 18.7-20.8\%) in the Atlantic specimens and 22.2\% (21.2-23.0\%) in Pacific specimens. Although no overlap was seen, this was apparently overlooked, as Rivas and Warlen (1967: 254) stated that of the five characters that showed significant differences among individuals of the two populations (dorsal- and anal-fin heights, length of last dorsal-fin ray, and upper and lower caudal-fin lobe lengths) all showed broad overlap. Inter-population differences were also seen in the number of gill rakers, but this was attributed to difficulties in counting gill rakers in larger specimens, and the mean size differences among the Atlantic and Pacific samples. Rivas and Warlen (1967) concluded that the slight differences noted in a few morphological characters among the Atlantic and Pacific specimens did not warrant separating them into two species, or even subspecies. At that time, however, the extent of cryptic speciation in the genus Albula revealed by molecular studies (Shaklee and Tamaru 1981, Colborn et al. 2001) was not known.

There is also some evidence that the shape of the otoliths (sagittae) differ among individuals from Atlantic and Pacific populations of $A$. nemoptera, although more individuals need to be examined for confirmation. Frizzell (1965) first figured and described a pair of otoliths, $14.3 \mathrm{~mm}$ in length, obtained from a specimen of $A$. nemoptera from the Caribbean coast of Colombia. The sagittae obtained from a specimen of A. nemoptera collected near Acapulco in the eastern Pacific (Fig. 1) were of similar size (12.3-12.5 mm) and showed clear differences when compared to those of Frizzell's Caribbean specimen. The most prominent difference was a pronounced dome on the dorsal margin of each sagitta in the region of the vertical midline in the Pacific specimen (Fig. 1). Frizzell (1965) mentioned that a "tiny dome" was present in the same region of the sagittae in the Caribbean specimen, but the dorsal outline of the sagittae in that specimen was relatively flat (see Pl. 4, Fig. 5a and 5b of Frizzell 1965).

Molecular Evidence for Cryptic Species: As mentioned above, since the work of Rivas and Warlen (1967) molecular methods have revealed an increasing number of marine organisms that show ancient genetic divergences with little or no change in external morphology (Rocha-Olivares et al. 1999, Quattro et al. 2001, 2006). Cryptic speciation is especially prominent in the bonefishes, in which few morphological differences are evident in lineages that have been separated for an estimated 20-30 million years (Shaklee and Tamaru 1981, Colborn et al. 2001, K. Hidaka et al., 2008). Where morphological characters have been found that can supposedly discriminate among bonefish species, they have not always proved reliable and can lead to misidentifications (Pfeiler et al. 2006). In the two sibling species of bonefishes from the A. vulpes complex that inhabit the eastern Pacific (Albula sp. 


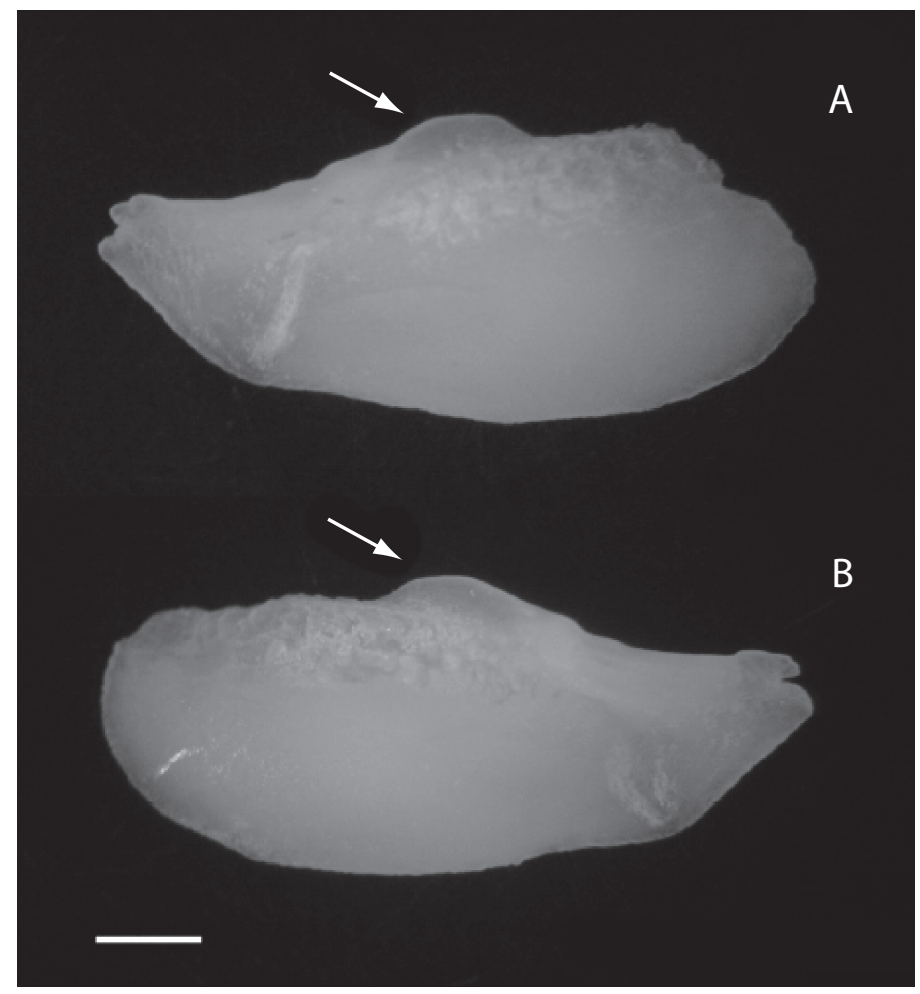

Fig. 1. Medial views of left sagitta (A) and right sagitta (B) from an adult specimen (283 mm SL) of Albula nemoptera (=A. pacifica) collected in January, 2006 near Laguna Chautengo, $\sim 80 \mathrm{~km}$ SE of Acapulco, Guerrero, Mexico [16 $31^{\prime} 26^{\prime \prime} \mathrm{N}$, 99¹6’36"W; catalog no. CIAD 06-203 (Centro de Investigación en Alimentación y Desarrollo, A.C. -Unidad Guaymas, Sonora)]. Arrows show the prominent dome on the dorsal margin. Scale bar $=2 \mathrm{~mm}$.

Fig. 1. Vistas mediales de la sagitta izquierda (A) y la sagitta derecha (B) de un espécimen adulto (283 mm longitud estándar) de Albula nemoptera (=A. pacifica) recolectado en enero de 2006 cerca de Laguna Chautengo, $\sim 80 \mathrm{~km}$ al sureste de Acapulco, Guerrero, México [16³1'26"N, 99¹6’36"W; número de catalogo CIAD 06-203 (Centro de Investigación en Alimentación y Desarrollo, A.C. -Unidad Guaymas, Sonora)]. Las flechas demuestran el domo prominente en el margen dorsal. Línea de escala $=2 \mathrm{~mm}$.

A and $\mathrm{C}$ ), analyses of 16 morphometric and 8 meristic characters ( $N=7$ for each species) were unable to distinguish between the two lineages which show a mitochondrial DNA cytochrome $b(C y t \mathrm{~b})$ divergence of $\sim 5.3 \%$ (E. Pfeiler et al., unpublished). Although the application of molecular methods to define species boundaries is controversial, these methods can be especially useful in taxa such as the bonefishes where morphological characters alone provide poor resolution (Wiens and Penkrot 2002). In light of the recent findings on cryptic speciation in the bonefishes, therefore, it is not surprising that Rivas and Warlen (1967) found only slight differences in morphology among their Atlantic and Pacific specimens.

Because gene flow among western Atlantic and eastern Pacific populations of $A$. nemoptera has been restricted by the Isthmus of Panama for about 3.5 million years (Coates et al. 1992), the expected genetic divergence among the two populations can be estimated based on results obtained from known sister species of marine fishes separated by the Isthmus (geminate species). These predictions can then be used to address the issue of whether the Atlantic and Pacific populations of $A$. nemoptera should be considered separate species. Molecular clock 
estimations for the Cytb gene in bony fishes are roughly $1.0-1.5 \%$ sequence divergence per million years (Bermingham et al. 1997, Banford et al. 2004). If we assume that Atlantic and Pacific populations of A. nemoptera were initially isolated by the Isthmus of Panama (but see Knowlton et al. 1993 and Marko 2002), expected sequence divergence between the two populations is $\sim 3.5-5.3 \%$. The mean genetic divergence (uncorrected $p$ distance and Kimura's [1980] 2-parameter [K2P] distance) between A. nemoptera from the Pacific and the previously unidentified Albula sp. E (Colborn et al. 2001) from Bahia, Brazil is $4 \%$ (Pfeiler et al. 2006, Bowen et al. 2008), within the expected range, and also within the range of Cytb divergences reported for sister species of fishes (Johns and Avise 1998).

The accumulated evidence indicates that Albula sp. E, genetically characterized by tissue samples from a Brazilian fish market, actually represents the Atlantic A. nemoptera. First, the Pacific A. nemoptera is linked to the Atlantic Albula sp. E by a unique amino acid substitution in the translated $C y t b$ gene segment which is absent from all other members of the genus Albula (Pfeiler et al. 2006). Second, molecular phylogenetic trees constructed with a variety of assumptions consistently show that $A$. nemoptera from various eastern Pacific localities (Mexico, Costa Rica, and El Salvador) and Albula sp. E are sister lineages (Pfeiler et al. 2006, Bowen et al. 2008). Third, the occurrence of $A$. nemoptera has been confirmed in the region of Bahia, Brazil, where the tissue samples for Albula sp. E. were obtained (Lopes and Sampaio 2002). However, voucher specimens of Albula sp. E are not yet available (Colborn et al. 2001, Pfeiler et al. 2006), as Atlantic A. nemoptera is rare and directed efforts to collect specimens have not been successful. Vouchers are desirable to link the morphological identification (Atlantic A. nemoptera) and genetic characterization (Albula sp. E), but this lack does not directly impact the morphological, biogeographic, and genetic arguments for resurrecting $A$. pacifica as the proper name for the form inhabiting the eastern
Pacific. In particular, all genetic analyses show that that form is millions of years divergent from other members of the genus Albula.

In reference to Hildebrand's (1963) placement of $A$. pacifica (as D. pacifica) into the synonymy of $A$. nemoptera, Berry (1964) stated "...once a specific name has been proposed that distinguishes a geographically isolated form from its congener, it is usually better (certainly in this instance) to retain the name until adequate material is available and adequate assessment is made to properly define the relationship". The molecular evidence now available, indicating that cryptic speciation is widespread in the bonefishes, would certainly cast doubt on whether a purely morphological comparison of geographically isolated bonefish populations is sufficient to adequately define relationships. In addition, the evidence presented here, including slight morphological differentiation, strongly indicates that Atlantic and Pacific populations of A. nemoptera are indeed valid sister species which have diverged to an extent similar to other recognized sister species now geographically isolated by the Isthmus of Panama. On these grounds, and considering that reproductive isolation is ancient and absolute, I propose that the name A. pacifica (Beebe, 1942) be reinstated for the population of $A$. nemoptera from the eastern Pacific. Suggested common names are Shafted Bonefish for A. pacifica and Threadfin Bonefish for the western Atlantic A. nemoptera (Bowen et al. 2008).

The first published record of A. pacifica (as D. nemoptera) is apparently the report of Myers (1936) on a specimen (USNM 75547) obtained from Acapulco, Guerrero, Mexico (Beebe 1942). This same specimen was later figured by Hildebrand (1963: 143, Fig. 24). Beebe (1942) also considered the illustration of a specimen of a Shafted Bonefish from the southern Gulf of California incorrectly labeled as A. vulpes (Kumada and Hiyama 1937: 47, Pl. 5; also see Walford 1939), as the second published record of A. pacifica. Albula pacifica (as A. nemoptera) has also been figured by Bussing and López (1993: 37), Allen and Robertson 
(1994: 41) and Robertson and Allen (2006). The holotype of Dixonina (=Albula) pacifica, originally deposited in the Department of Tropical Research of the New York Zoological Society (Beebe 1942, Mead 1958), is now housed at the California Academy of Sciences, San Francisco, California, USA (catalog no. SU 46486).

\section{ACKNOWLEDGMENTS}

I am grateful to B.W. Bowen and L.T. Findley for kindly reviewing and suggesting improvements to an earlier draft of the manuscript. I also thank B. Bitler, J. Egido-Villarreal, J.-P. Gallo-Reynoso, T.A. Markow, J. Pugh, R. Ulloa and T. Watts for their help. Much of the molecular research on eastern Pacific bonefishes described herein was supported in part by NSF grant DEB-0346773 to T.A. Markow.

\section{RESUMEN}

El nombre Albula nemoptera (Fowler, 1911) se aplica actualmente a las poblaciones del macabí de hebra (Albuliformes: Albulidae) de las aguas costeras tropicales del Atlántico Occidental y el Pacifico Oriental. En este artículo se presenta una revisión breve de la taxonomía y nomenclatura de $A$. nemoptera, y se sugiere que la evidencia morfológica, biogeográfica y molecular apoya el reestablecimiento del nombre $A$. pacifica (Beebe, 1942) para la población de $A$. nemoptera del Pacifico Oriental.

Palabras clave: ADN mitocondrial, Elopomorpha, especiación, especies crípticas, sistemática molecular.

\section{REFERENCES}

Allen, G. R. \& D. R. Robertson. 1994. Fishes of the Tropical Eastern Pacific. University of Hawaii Press, Honolulu, Hawaii, USA. 332 p.

Balart, E.F., J.L. Castro-Aguirre, D. Aurioles-Gamboa, F. García-Rodríguez \& C. Villavicencio-Garayzar. 1995. Adiciones a la ictiofauna de Bahía de la Paz, Baja California Sur, México. Hidrobiológica 5: 79-85.

Banford, H. M., E. Bermingham \& B. B. Collette. 2004. Molecular phylogenetics and biogeography of transisthmian and amphi-Atlantic needlefishes (Belonidae: Strongylura and Tylosurus): perspectives on New World marine speciation. Mol. Phylogenet. Evol. 31: 833-851.

Beebe, W. 1942. Eastern Pacific expeditions of the New York Zoological Society. XXX. Atlantic and Pacific fishes of the genus Dixonina. Zoologica 27: 43-48.

Bermingham, E., S. S. McCafferty \& A. P. Martin. 1997. Fish biogeography and molecular clocks: perspectives from the Panamanian Isthmus, p. 113-128. In T. D. Kocher \& C. A. Stepien (eds.). Molecular Systematics of Fishes. Academic, San Diego, California, USA.

Berry, F. H. 1964. Review and emendation of: family Clupeidae, pp. 257-454. Copeia 1964: 720-730.

Bowen, B.W., S.A. Karl \& E. Pfeiler. 2008. Resolving evolutionary lineages and taxonomy of bonefishes (Albula spp.), p. 147-154. In J.S. Ault (ed.). Biology and Management of the World Tarpon and Bonefish Fisheries. CRC, Boca Raton, Florida, USA.

Bussing, W.A. \& M.I. López S. 1993. Demersal and pelagic inshore fishes of the Pacific coast of lower Central America. Rev. Biol. Trop. Special Publication. 164 p.

Castro-Aguirre, J.L., H. Espinosa Perez \& J. J. SchmitterSoto. 1999. Ictiofauna estuarino-lagunar y vicaria de México. Limusa, México DF. 711 p.

Coates, A.G., J.B.C. Jackson, L.S. Collins, T.M. Cronin, H.J. Dowsett, L.M. Bybell, P. Jung \& J.A. Obando. 1992. Closure of the Isthmus of Panama: the nearshore marine record of Costa Rica and western Panama. Geol. Soc. Am. Bull. 104: 814-828.

Colborn, J., R.E. Crabtree, J.B. Shaklee, E. Pfeiler \& B.W. Bowen. 2001. The evolutionary enigma of bonefishes (Albula spp.): cryptic species and ancient separations in a globally distributed shorefish. Evolution 55: 807-820.

Fowler, H.W. 1911. A new albuloid fish from Santo Domingo. Proc. Acad. Nat. Sci. Philadelphia 62: 651-654.

Frizzell, D.L. 1965. Otolith-based genera and lineages of fossil bonefishes (Clupeiformes, Albulidae). Senckenbergiana Lethaea 46a: 85-110.

Hidaka, K., Y. Iwatsuki \& J.E. Randall. 2008. A review of the Indo-Pacific bonefishes of the Albula argentea complex, with a description of a new species. Ichthyol. Res. 55: 53-64.

Hildebrand, S.F. 1963. Family Albulidae, p. 132-147. In H.B. Bigelow et al. (eds.). Fishes of the Western North Atlantic, Part 3. Sears Foundation for Marine 
Research (Memoir No. I), New Haven, Connecticut, USA.

Johns, G.C. \& J.C. Avise. 1998. A comparative summary of genetic distances in the vertebrates from the mitochondrial cytochrome $b$ gene. Mol. Biol. Evol. 15: 1481-1490.

Kimura, M. 1980. A simple method for estimating evolutionary rate of base substitutions through comparative studies of nucleotide sequences. J. Mol. Evol. 16: $111-120$.

Knowlton, N., L.A. Weigt, L.A. Solórzano, D.K. Mills \& E. Bermingham. 1993. Divergence in proteins, mitochondrial DNA, and reproductive compatibility across the Isthmus of Panama. Science 260: 1629-1632.

Kumada, T. \& Y. Hiyama. 1937. Marine Fishes of the Pacific Coast of Mexico. Nissan Fish. Inst., Odawara, Japan. 75 p.

Loebmann, D. \& J.P. Vieira. 2005. Composição e abundância dos peixes do Parque Nacional de Lagoa do Peixe, Rio Grande do Sul, Brasil e comentários sobre a fauna acompanhante de crustáceos decápodos. Rev. Atlântica 27: 131-137.

Lopes, P.R.D. \& C.L.S. Sampaio. 2002. Ocorrência de Albula nemoptera (Fowler, 1910) (Actinopterygii: Albulidae) no litoral do estado da Bahia, Brasil (Oceano Atlântico Ocidental). Boletim do Museu de Biologia Mello Leitão 13: 27-32.

Marko, P.B. 2002. Fossil calibration of molecular clocks and the divergence times of geminate species pairs separated by the Isthmus of Panama. Mol. Biol. Evol. 19: 2005-2021.

Mead, G.W. 1958. A catalog of the type specimens of fishes formerly in the collections of the Department of Tropical Research, New York Zoological Society. Zoologica 43:131-134.

Metzelaar, J. 1919. Report on the Fishes Collected by Dr. J. Boeke in the Dutch West Indies 1904-1905, with Comparative Notes on Marine Fishes of Tropical West Africa. Reprinted 1967, A. Asher, Amsterdam, The Netherlands. 314 p.

Myers, G.S. 1936. A third record of the albulid fish Dixonina nemoptera Fowler, with notes on an albulid from the Eocene of Maryland. Copeia 1936: 83-85.

Nelson, J.S., E.J. Crossman, H. Espinosa-Pérez, L.T. Findley, C.R. Gilbert, R.N. Lea \& J.D. Williams. 2004. Common and Scientific Names of Fishes from the United States, Canada, and Mexico, $6^{\text {th }}$ ed.
Am. Fish. Soc., Special Publication 29, Bethesda, Maryland, USA. 386 p.

Pfeiler, E., J. Colborn, M. R. Douglas \& M. E. Douglas. 2002. Systematic status of bonefishes (Albula spp.) from the eastern Pacific Ocean inferred from analyses of allozymes and mitochondrial DNA. Env. Biol. Fish. 63: 151-159.

Pfeiler, E., B.G. Bitler \& R. Ulloa. 2006. Phylogenetic relationships of the Shafted Bonefish Albula nemoptera (Albuliformes: Albulidae) from the eastern Pacific based on cytochrome $b$ sequence analyses. Copeia 2006: 778-784.

Quattro, J.M., M.R. Chase, M.A. Rex, T.W. Greig \& R.J. Etter. 2001. Extreme mitochondrial DNA divergence within populations of the deep-sea gastropod Frigidoalvania brychia. Mar. Biol. 139: 1107-1113.

Quattro, J.M., D.S. Stoner, W.B. Driggers, C.A. Anderson, K.A. Priede, E.C. Hoppmann, N.H. Campbell, K.M. Duncan \& J.M. Grady. 2006. Genetic evidence of cryptic speciation within hammerhead sharks (Genus Sphyrna). Mar. Biol. 148: 1143-1155.

Rivas, L.R. \& S.M. Warlen. 1967. Systematics and biology of the bonefish, Albula nemoptera (Fowler). Fish. Bull. 66: 251-258.

Robertson, D.R. \& G.R. Allen. 2006. Shorefishes of the Tropical Eastern Pacific: an Information System. CD-ROM, version 2.0. Smithsonian Tropical Research Institute, Balboa, Panama.

Rocha-Olivares, A., R.H. Rosenblatt \& R.D. Vetter. 1999. Cryptic species of rockfishes (Sebastes: Scorpaenidae) in the southern hemisphere inferred from mitochondrial lineages. J. Hered. 90: 404-411.

Shaklee, J.B. \& C.S. Tamaru. 1981. Biochemical and morphological evolution of Hawaiian bonefishes (Albula). Syst. Zool. 30: 125-146.

van der Heiden, A.M. \& L.T. Findley. 1990. Lista de los peces marinos del sur de Sinaloa, México. Anales del Instituto de Ciencias del Mar y Limnología, Universidad Nacional Autónoma de México (1988) 15: 209-224.

Walford, L.A. 1939. "Marine fishes of the Pacific coast of Mexico", by Kumada and Hiyama [review]. Copeia 1939: 119.

Wiens, J.J. \& T.A. Penkrot. 2002. Delimiting species using DNA and morphological variation and discordant species limits in spiny lizards (Sceloporus). Syst. Biol. 51: 69-91. 